\title{
Beyond the Bucket List: Identity-Centered Religious Calling, Being, and Action Among Parents
}

David C. Dollahite

Brigham Young University, david_dollahite@byu.edu

Loren D. Marks

Brigham Young University - Provo, loren_marks@byu.edu

Taleah M. Kear

Brigham Young University - Provo

Brittany M. Lewis

Brigham Young University - Provo

Megan L. Stokes

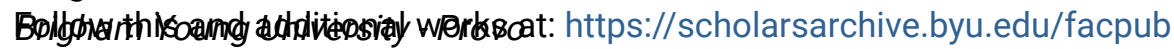

Part of the Other Social and Behavioral Sciences Commons

\section{Original Publication Citation}

Dollahite, D. C., Marks, L. D., *Kear, T. M., *Lewis, B. M., \& *Stokes, M. L. (2018). Beyond the bucket list: Identity-centered religious calling, being, and action among parents. Psychology of Religion and Spirituality, 10, 44-54.

\section{BYU ScholarsArchive Citation}

Dollahite, David C.; Marks, Loren D.; Kear, Taleah M.; Lewis, Brittany M.; and Stokes, Megan L., "Beyond the Bucket List: Identity-Centered Religious Calling, Being, and Action Among Parents" (2017). Faculty Publications. 4851.

https://scholarsarchive.byu.edu/facpub/4851

This Peer-Reviewed Article is brought to you for free and open access by BYU ScholarsArchive. It has been accepted for inclusion in Faculty Publications by an authorized administrator of BYU ScholarsArchive. For more information, please contact ellen_amatangelo@byu.edu. 


\title{
Beyond the Bucket List: Identity-Centered Religious Calling, Being, and Action Among Parents
}

\author{
David C. Dollahite, Loren D. Marks, Taleah M. Kear, Brittany M. Lewis, and Megan L. Stokes \\ Brigham Young University
}

\begin{abstract}
From a positive family psychology perspective, this study explores identity-centered religious calling, being, and action among parents of youth, that is, what religious parents believe they are called to be and to do in relation to their adolescent children. Twenty-nine Christian, Jewish, and Muslim families of youth ( $N=58$ participants) were asked what they considered most important for them "to be" and "to do" as parents of faith. Qualitative analyses were conducted to determine major themes of responses. Parents indicated they believed they were called to be (A1) an example, (A2) authentic, and (A3) consistent; called to provide their children with (B1) support, (B2) love, and (B3) help; and called to teach their children $(\mathrm{C} 1)$ religious values, $(\mathrm{C} 2)$ the faith tradition, and (C3) the importance of religious identity. This study emphasizes the potential of identity-centered calling, being, and action as valuable constructs in religious/spiritual formation. Implications are discussed regarding how religious and secular education may benefit from reconstructing emphasis on developing one's being.
\end{abstract}

Keywords: identity, calling, being, religion, parenting

Although we refer to ourselves as human beings, social scientists spend relatively little time exploring matters of being-the deeper "existential" issues dealing with what it means to be, to become, or to act on deeply held beliefs and responsibilities. Social science has produced thousands of studies that include "wellbeing" as an outcome, but few focus on identity-centered "being" or "calling" as a main topic of study. There are good reasons for this. It is not easy to address these kinds of questions because (a) it takes substantial effort for researchers and participants to address these issues, and (b) trust must be established between researchers and participants in order to truly delve into these deeper matters.

Despite these challenges, we believe that asking people to reflect on their identity-centered religious being, calling, and action can provide rich opportunities for additional insights. These kinds of questions may prompt people to reflect on what is most important to them and therefore provide valuable data on being a better parent, spouse, child, and human being.

For most parents, these questions likely concern their parental obligations and hopes. For most religious parents, two of the things they are likely to care most deeply about are their faith and their children. Thus, these kinds of questions for religious parents are full of meaning because their own identity is closely connected to

This article was published Online First April 27, 2017.

David C. Dollahite, Loren D. Marks, Taleah M. Kear, Brittany M. Lewis, and Megan L. Stokes, School of Family Life, Brigham Young University.

The first author appreciates funding from the Eliza R. Snow Fellowship and the Brigham Young University Religious Studies Center. We also are grateful to Heather Kelley for insightful and helpful comments and suggestions.

Correspondence concerning this article should be addressed to David C. Dollahite, School of Family Life, Brigham Young University, 2092B JFSB, Provo, UT 84062. E-mail: david_dollahite@byu.edu their children and their faith. In a real sense, religious beliefs are ideas and ideals about what one should be and become-and about what God hopes one will be and become.

Our focus on identity-centered religious being, calling, and action occurs in a cultural climate that emphasizes amusing and exciting activities and a social science era that devotes considerable conceptual and empirical attention to outward activities-to behaviors, outcomes, practices, and productivity. The social sciences have devoted little attention to matters of identity-centered religious calling, being, and action.

In this article, we take a step down the path of studying identitycentered religious calling, being, and action by exploring the answers given by practicing Christian, Jewish, and Muslim parents of adolescents to the question, "What do you consider to be the most important things for you to be or do as a mother/father of faith?" We believe this question addresses the three dimensions of identity-centered religious calling, being, and action in ways that evoke deep thought about things that matter most to religious parents.

\section{Brief Literature Review of the Main Concepts}

We are not aware of any contemporary social science theory that systematically connects the ideas of identity-centered religious calling, being, and action, yet these concepts seem to belong together. Next, we briefly overview the main concepts.

\section{Identity as the Center of Religious Calling, Being, and Action}

Identity is a major construct in developmental psychology, and scholars have argued that religion can provide unique contributions to identity (Erikson, 1968; Erikson \& Erikson, 1997; King, 2003). Erik and Joan Erikson stated, "An adult must be ready to become a numinous model in the next generation's eyes and to act 
as a judge of evil and a transmitter of ideal values" (Erikson \& Erikson, 1997, p. 70). Because "numinous" refers to religious experience, this suggests a religious identity with generative implications.

Schachter and Ventura (2008) developed the idea that parents are "identity agents" in their children's lives and "co-participate" in the development of their children's identity (p. 449). Schachter and Ventura further mentioned six components of identity agency in parents: (a) identity concern (caring about children's developing identity), (b) goals (having goals about children's identity development), (c) praxis (implementing practices to help children's identity development), (d) assessment (monitoring children's identity development), (e) implicit theory (holding implicit psychological theories that guide their practice regarding identity development), and (f) reflexivity (reflecting on, reassessing, and refining identity development goals and practice for children). They tested this model with a qualitative study of a sample of exemplary Orthodox Jewish parents in Israel and found some support for these ideas.

\section{Identity-Centered Religious Calling}

The idea of parenting as a calling has been addressed by positive psychologist Martin Seligman (2002) and others (Coulson, Oades, \& Stoyles, 2012a, 2012b), including sociologist Robert Bellah (Bellah, Madsen, Sullivan, Swidler, \& Tipton, 1985). Previous research has similarly noted that many mothers and fathers view their parenting role as having sacred significance (Mahoney, Pargament, Murray-Swank, \& Murray-Swank, 2003). Further, Pargament and Mahoney (2005) found that parents who aspire to live in a manner congruent with their religious beliefs tend to invest more effort in being committed to their role as a parent.

The three Abrahamic faiths (Judaism, Christianity, Islam) include the idea that people can receive and discern some kind of life mission or purpose from God (Agius \& Chircop, 1998). Catholic and Orthodox Christians typically use the term "vocation," whereas Protestant Christians often use the term "calling." In Judaism, the Hebrew term avodah (work/worship) is used to refer to a person's work or service for God. In Islam, the Arabic phrase al esteklaf indicates that every human being was created to be God's successor on the earth and has the ability (and is recommended) to be merciful, just, and generous, and to embody characteristics of God.

In our framework, religious calling is when identity-centered religious being meets identity-centered religious action. Calling is about what one believes one should do in this world to most fully live out one's sense of being and identity. In this article, we use the term religious calling to refer to what parents consider to be the most important things for them to be and do as religious parents (i.e., "What am I called to be and do?").

\section{Identity-Centered Religious Being}

In his introduction to Paul Tillich's The Courage to Be, Harvard theologian Harvey Cox asserted, 'Hamlet's 'To be or not to be' is indeed the question. It is everyone's question, and it is also the one that underlies all the questions asked by the various academic specialties" (Tillich, 2014, p. xiv, emphasis in original). Tillich (2014) himself argued that the "to be" question involves not only whether to exist or not-it also explores what kind of person one should be. Further, Tillich posited, the universal challenge is how to continue being the person one believes one ought to be in the face of life's daunting anxieties such as guilt, failure, meaninglessness, and death. In other words, issues of belief, behavior, and being are intertwined.

Few experiences provoke an exploration of identity-centered being more than imminent death. When one's earthly existence is coming to an end, deep introspection about what one has been and done often occurs. In her chronicle as a hospice nurse entitled The Top Five Regrets of the Dying, Bronnie Ware (2011) summarized her findings, "Of all of the regrets and lessons shared with me as I sat beside their beds, the regret of not having lived a life true to themselves was the most common one of all" (p. 39, emphasis in original). Part, if not much, of what it would mean to have "lived a life true to one's self" would include having tried to live in way that was consistent with one's deepest identity. For many, this would center on their family and faith identities.

Religion and spirituality often have profound influence on a person's identity, sense of calling, core aspects of being, and social action. We believe that matters of being are a vital component of life in addition to doing, but being tends to be neglected-even ignored. We propose that, particularly for the psychology of religion and spirituality, greater attention to questions of identitycentered calling, being, and action-in relation to ones deepest held beliefs and values-is worth pursuing.

Psychology has been the social science most open to issues of being. Abraham Maslow wrote extensively on being (Maslow, 1998), and Carl Rogers developed a set of ideas and clinical practices focused on being (Rogers, 1975). Although a relatively small but passionate group of psychologists remain devoted to existential and person-centered approaches to psychology, most contemporary psychologists have been trained in other approaches. Although clinical emphasis on being has declined, being is still central to being human and for many people in the world, two core aspects of their being are their family and their faith.

In our framework, we link identity-centered being and calling in the following way: Religious being refers to one's core sense of identity in relation to God, to one's self, and to one's family; religious calling refers to one's strongly held, sense of identitybased sacred responsibilities to God and to other people or groups, including family, friends, peer groups, or organizations (i.e., "As a religious parent, what am I called to be and do?").

\section{Identity-Centered Religious Action}

The contemporary cultural fascination with consumption, entertainment, and thrill seeking is typified by the 2008 box office hit The Bucket List, which followed two terminally ill protagonists through a rapid series of exciting and eclectic "must-do" activities. That everyone should fulfill a bucket list of things to do before death is now a pervasive, powerful, and-potentially-problematic idea (Mead, 2014). Social science also tends to overwhelmingly focus on behaviors and related cognition. Activities and behaviors are vital to consider, but isn't there something deeper?

Herein we explore the desire that human beings have to be and to become their better selves through identity-centered action rather than merely consumption-based activities. By consumption- 
based activities, we mean activities that are an end in and of themselves. By identity-centered religious action, we mean actions that are consciously intended to be a means to fulfill or develop part of one's core religious identity. Thus, in our framework religious action refers to what religious parents believe they should do in relation to their children (i.e., "What am I called to do?").

Psychologist Steven Reiss (2015) stated that "psychologists pay little attention to conscious motives, core values, and goals" (p. 14) and believe that unconscious motives, external forces, or internal biological/genetic influences drive most behavior. Reiss also countered the assumptions of many that it is not possible to obtain valid, reliable data from self-report methods. He cites his and his colleagues' findings, based on tens of thousands of subjects from three continents that indicate that asking people directly is often more valid and reliable than indirect approaches.

Figure 1 provides a framework that links these concepts to each other and with findings we report in the findings section. The top three boxes include major concepts. The part of our interview question that assesses that concept is in quotes. Each concept is in dynamic relationship with the other concepts. The nine major findings are in dynamic relation with and are supportive of the other concepts.

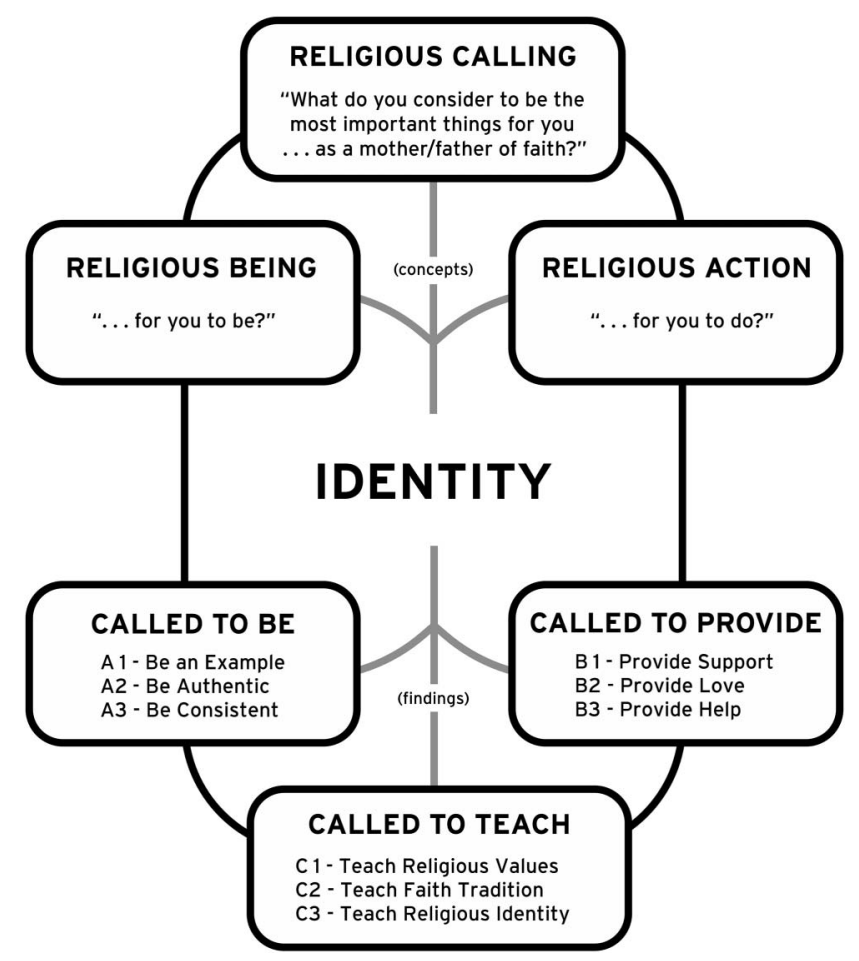

Figure 1. Relationships between major concepts and findings. The top three rectangles are concepts (with pertinent portions of the interview question in quotes). The bottom three rectangles are the nine major findings (labeled A1 to C3).

\begin{abstract}
Method

\section{Participants}

We employed an exemplar approach to our sample. Damon and Colby (2013) argued

Exemplar studies begin from the assumption that social scientists need to include the most mature in their samples if they are to understand the true scope of morality. These studies are based in a belief that all can aspire to more elevated selves, and they document the fact that many people do achieve this goal. (p. 24)
\end{abstract}

The participants in this study consisted of 29 married couples ( 29 husbands and 29 wives) from the New England area of the United States $(N=58)$. The mothers and fathers ranged in age from 27 to 62 years, with a mean age of 46 years. The distribution of religious denominations of the couples was three Muslim, five Jewish (Modern Orthodox, Conservative, Reformed), three Catholic, six Conservative Protestant (Baptist, Pentecostal, Nondenominational Christian), six Mainline Protestant (Episcopalian, Methodist, Lutheran, United Church of Christ), and six New Christian Religious Traditions (faiths founded since 1800, i.e., Jehovah's Witnesses, Latter-day Saints, and Seventh-day Adventists). Average length of marriage was 22 years. Average number of children per couple was three, with a range of one to seven children per couple. Age of youth ranged from 10 to 25 years old, with a mean age of 15.5 years. Socioeconomic status of the couples varied from lower-middle to upper-middle class. The average family attended religious activities more than once a week, spent about $18 \mathrm{hr}$ per week in religious activity, and donated an average of $7 \%$ of their income to their faith.

\section{Selection and Interview Procedures}

The data for this project are part of a larger qualitative research initiative - the American Families of Faith project (AmericanFamiliesofFaith.byu.edu), which includes in-depth interviews with 198 diverse U.S. religious families. The data collection process for the 29 families addressed in the present study (those who were asked the main research question) were as follows: after obtaining institutional review board approval, the first author met with 25 congregational leaders from various faith communities in New England and asked if they were willing to recommend "2-3 married couples with a teen or young adult child in your congregation that you consider strong in their faith and that you consider successful in applying religious principles in their family relationships."

Given their level of attendance, monetary contribution, and hours spent in religious service, and given that families were recommended by their religious leaders as being "strong in their faith" and "successful . . . in their family relationships," we consider this sample of interviewed families to be exemplars, or exemplary parents, as determined by faith community leaders.

The families were then contacted by phone and mail, and the first author explained the procedures of the study and requested the participation of parents and their adolescent child(ren). He met with one to three families from each congregation. Interviews were conducted with the parents and youth together, typically in homes or religious buildings. Interviews generally lasted about $2 \mathrm{hr}$ and 
were tape-recorded. Questions focused on how family members thought their religion and family life were connected. Participants received compensation ( $\$ 20$ per parent and $\$ 10$ per adolescent).

The first author personally conducted all the interviews using intensive interviewing. According to Lofland, Snow, Anderson, and Lofland (2005), this methodology involves "the use of an interview guide consisting of a list of open-ended questions that direct conversation without forcing the interviewee to select preestablished responses" (p. 17). The interviews consisted of 26 open-ended questions on faith traditions, living one's faith in a secular culture, how parents transmitted their faith to their children, and how parents and youth communicate about religion. The interviews were semistructured, allowing the interviewer to guide the conversations while remaining attentive to participants' experiences and views. The interview question that was used for this article was "What do you consider to be the most important things for you to be or do as a mother/father of faith?" Interviews were transcribed, and the NVivo qualitative analysis program was used. Because of the frequent presence of dialogue between parents, we included both mothers' and fathers' responses in the same interview transcripts.

Some researchers argue that family members should be interviewed individually to avoid other-influenced responses. In the present study, parents and adolescents were interviewed together to allow the interviewer to observe family processes and to allow family members to interact and add to, revise, or challenge what others said (Lofland et al., 2005). Babbie (2004) has stated that interviewing people together "frequently brings out aspects of the topic that would not have been anticipated by the researcher and would not have emerged from interviews with individuals" (p. 303). Seymour, Dix, and Eardley (1995) have stated that joint interviews produce more complete data as interviewees fill in each other's gaps and memory lapses. This has been our experience.

\section{Reflexivity and Bias}

Qualitative scholars are typically expected to be aware of their own biases and attempt to factor that into the research process (Daly, 2007). We tried to maintain impartiality while being aware of our personal tendencies to emphasize the benefits of religiosity. The interviews incorporated structured and unstructured questions about possible negative effects of participants' religious beliefs and practices. To balance the potential biases of the interviewer (first author) and second author, three students were significantly involved in the coding and interpretation process. In addition, the lead authors (both males) attempted to counter potential gender bias by having the three female student coders act relatively independently in the coding process. Specifically, the three students did all of the open and axial coding, as well as the identifying of themes. The two faculty members only assisted in the later stages of the axial coding processes and in finalizing of thematic labels.

\section{Analyses}

Consistent with grounded theory methods (Strauss \& Corbin, 1998), we did not rely on preexisting theories or research findings to guide the coding process. Rather, students coded based on what was in the transcripts without regard for previously identified concepts. We focused our analysis on interview questions regarding religious parenting and parents' hopes for their children's futures, with an aim to explore what parents feel it is most important to be and $d o$. Analysis was completed in three stages.

Stage 1: Open coding. Data came in response to the question "What do you consider to be the most important things for you to be or do as a mother/father of faith?" In the first stage of analysis, open coding identified more than 15 potential themes. Interrater reliability was not assessed statistically but through consensus between the coders. There was complete agreement on nearly all conceptual codes, and authors discussed any divergent codes until all coders concurred with the code. Thus, interrater reliability would be considered very strong.

Stage 2: Axial coding. Consistent with the team-based qualitative method of Marks (2015), we closely examined concepts or themes identified during stage one (open coding) and eliminated "pretenders" (i.e., concepts that seemed important at first, but were not supported across interviews) from "contenders" (i.e., salient and frequent concepts that did emerge across interviews; p. 496). This process focused our attention on nine remaining concepts (as documented in Table 1, those included [1] be an example, [2] be authentic, [3] be consistent, [4] give support, [5] give love, [6] give help, [7] teach religious values, [8] teach the faith tradition, and [9] teach religious identity.) Those firmly established concepts allowed us to engage in what Daly (2007) has called "axial coding," which "involves looking at relationships within a category and between categories" (p. 234).

Stage 3: Final process of axial coding. We examined relationships and connections between the nine conceptual categories, and from those analyses, the final grouping of three overarching categories was determined. The nine conceptual categories were examined and deemed to comprise three different categories of parental aspiration: (a) called to be, (b) called to provide, and (c) called to teach (Table 1 shows the numeric breakdown for both the nine conceptual categories and for the three overarching categories [i.e., "called "to be," "to provide," and "to teach"]).

Categorical overlap in qualitative coding. In qualitative coding, significant overlap in themes and concepts is considered

Table 1

Frequencies and Percentages of Codes for Themes and Subthemes

\begin{tabular}{lrrrrrrrrr}
\hline & \multicolumn{2}{c}{ Fathers } & & \multicolumn{2}{c}{ Mothers } & & \multicolumn{2}{c}{ Parents } \\
\cline { 2 - 3 } Themes and subthemes & $n=29$ & $\%$ & & $n=29$ & $\%$ & & $n=58$ & $\%$ \\
\hline A. Called to be: & 26 & 89.7 & & 24 & 82.8 & & 45 & 77.6 \\
1. An example & 17 & 58.6 & & 15 & 51.7 & & 32 & 55.2 \\
2. Authentic & 3 & 10.3 & & 4 & 13.8 & & 7 & 12.1 \\
3. Consistent & 3 & 10.3 & & 3 & 10.3 & & 6 & 10.3 \\
B. Called to provide: & 20 & 70.0 & & 23 & 79.3 & & 43 & 74.2 \\
1. Support & 7 & 24.1 & & 9 & 31.0 & & 16 & 27.6 \\
2. Love & 6 & 20.7 & & 9 & 31.0 & & 15 & 25.9 \\
3. Help & 7 & 24.1 & & 5 & 21.7 & & 12 & 20.7 \\
C. Called to teach: & 16 & 55.2 & & 19 & 65.5 & & 35 & 60.4 \\
1. Religious values & 10 & 34.5 & & 10 & 34.5 & & 20 & 34.5 \\
2. The faith tradition & 4 & 13.8 & & 3 & 10.3 & & 7 & 12.1 \\
3. Religious identity & 2 & 7.0 & & 6 & 20.7 & & 8 & 13.8 \\
\hline
\end{tabular}

Note. Percentages do not add up to $100 \%$ because only the highest three themes in each category are included in this table. 
problematic by most scholars, although some degree of conceptual overlap is quite common because participants' accounts or experiences often include multiple concepts (Daly, 2007; Gilgun, 2005). This is particularly true with narratives, which abound in our data set. We also note that our coding identified and categorized themes in expressed ideas rather than to attempt to separate people into groups. In other words, the themes do not represent an attempt to create a typology that classifies people into discrete groups, but rather to organize and distinguish between different concepts found in the data. Thus, the numbers reported in the text (and in Table 1) reflect the number of accounts that were coded into that thematic category. In fact, in some cases, comments made by the same parent were coded into more than one category, such as both "being authentic" and "being consistent." Fifty-six of the 58 interviewed parents (96\%) shared at least one coded parenting account. Only one father and one mother were not represented in coded accounts. Twenty of 29 mothers (69\%) and 19 of 29 fathers $(65 \%)$ had one or two coded accounts, whereas eight mothers (27\%) and 10 fathers (34\%) had three to four coded accounts. Only one parent had more than four (a mother with five). We will address these connections and occasionally overlapping narratives as we present findings.

\section{Findings}

There were three primary findings. Parents' responses focused on (a) being an example, being authentic, and being consistent $(89.7 \%$ of fathers and $82.8 \%$ of mothers made a related, coded response); (b) providing support, love, and help (mothers, 79.3\%; fathers, 70\%), and (c) teaching values, tradition, and identity (mothers, 65.5\%; fathers, 55.2\%). Percentages were based on the occurrence of a theme within a given participant's interview. Each category and subcategory will be discussed, with illustrative examples from the primary data. But first we present one narrative that includes the major ideas we address in more detail in the rest of the results.

A Chinese Christian father of two we interviewed said, "I [am] always thinking that I have to be a good parent for my child in terms of faith in God. This keeps pushing my efforts to keep growing in my faith for my children." This father clearly feels a religiously based parental calling and his words demonstrate both identity ("a good parent for my child") and generativity ("keep growing in my faith for my children”).

\section{As a Mother/Father of Faith, I Am Called to Be}

The most significant pattern within the responses of mothers and fathers was their emphasis on what they felt called to be. Of the identified narratives, nearly $85 \%$ of the parents brought this up in their responses. Parents described what they believed they needed to be in three respects: (a) be an example, (b) be authentic, and (c) be consistent. The differing dimensions of this primary theme are briefly highlighted by examples from the mothers' and fathers' narratives.

Be an example. Parents' desire to be an example emerged in the analysis as mothers and fathers described their responsibility to model behavior as a teaching method for their children. Fifty-two percent of mothers' responses and 59\% of fathers' responses fell into this subcategory, the largest subcategory in the study.
Malinda (all names are pseudonyms), a Pentecostal mother, shared her idea of how she can be an example: "Instill faith into them, and just be a testimony as well, because children pretty much do what they see. I try to be a good role model." An Orthodox Jewish mother, Rachel, indicated what she thought was most important: "To be a good example to them. To try to practice what I'm preaching and to give them enough foundation and support that they'll be very decent, good people when they grow up."

An even greater percentage of fathers noted their responsibility as a parent to be an example. Ed, a Seventh-day Adventist father, emphasized his duty to show the way through his example: "Being an example of trusting God and obeying God, and receiving the blessings and being the vehicle that God can use to show what his way can produce." A Modern Orthodox Jewish father, Ezra, described that his list of "oughts" included: "To be a role model. To set an example. I try to encourage my kids ... on Shabbas, to go to shul on time. They [my kids] don't always get there, but I always get there early." Ezra suggests that combining being a role model with loving encouragement, despite the outcome, is preferred.

Carlos, a Catholic father, reflected on his own father's example and how he wanted to likewise be "a good example" for his children:

I had a fantastic example in my father. My father was, and he is still, an incredible example for me. And I think that if I can pass some of that to my children through my own example, through talking or teachings or verbal example [that would be great]. And I think that our religion and our faith guide us to go through that. To be able to be a good example for me is incredibly important.

Note that in only five short sentences referencing both his own father and his own hopes as a parent, Carlos uses the word example five times.

Be authentic. A second significant theme we found was parents' desire to be authentic. Fourteen percent of mothers' responses and $10 \%$ of fathers' responses fell into this category. Responses coded within this theme included parents' desire to be real, genuine, and honest with their children. Both religious mothers and fathers felt an obligation to personally adhere to moral values and to their religious commitments.

Emily, a Baptist mother, said, "[I want] to be a person of integrity - and genuine and honest with myself and with my God and with my family members about issues of life." Leah, a Conservative Orthodox Jewish mother, also spoke of authenticity:

I presented to them an ever-expanding view of Judaism and that I was always honest about my angers with the religion, angers with the Rabbis, my own distress about the religion. [I wanted them to know] that whatever I chose to give them from the more Orthodox approach was something that I really believed in.

Mercy, a Baptist mother, shared,

I think the biggest thing that I try to be is authentic . . . in my faith. Just that it be real. . . We were talking about when people are first married, they only want people to see the good side. And it's easy to want to do that too as a parent ... to pretend like you are doing everything right. ... But [it's important to] just to be real, so that they know that you have struggles too. And we go to God to work out our struggles. 
Like these mothers, several fathers also valued and aspired to be authentic with their children. Shawn, a Baptist father, spoke of his desire "really to be a[n] authentic, genuine Christian myself, kind of a model mentor. Not an example of perfection . . . but I think to be genuine and authentic as someone who has a walk with Jesusliving faith." Shawn did not aspire to have his children view him as perfect, but as someone striving to live a faithful life. Eli, a Modern Jewish Orthodox father, similarly said that he wanted "to provide an ... authentic ... minimally-conflicted example of faith and behavior."

Be consistent. In addition to being an example and being authentic, parents in the study noted the importance of being consistent. Ten percent of both mothers' and fathers' responses were in this subcategory. One Catholic mother, Alisia, explained her idea of consistency: "It's more of the daily life of incorporating [religious beliefs] into everything we do, not [just] as a Sunday thing." Jennifer, a Jehovah's Witness mother, explained her interpretation of being consistent: "I think to continue to be faithful, no matter what my age is. I see that I'm always a mother [of faith]."

Gary, a Methodist father, shared, "[I want] to be consistent, even if it's a consistent pain in the neck." Gary's quip indicates that he understands that adolescents may not appreciate consistent parental monitoring of a teen's actions and whereabouts, but that it remains important for parents to persist in their concerned efforts for their children. George, a Lutheran father, illustrated how he can be consistent:

[I want to] set an example . . . in my daily life. Just to be somebody who's got . . . a soul . . . who's not interested just in the short term things. That's sort of a longer-term view. That and family, and all these things are important. . . . I mean even though I may not attend church all the time, I'm certainly a spiritual person. That's important to me.

George, Gary, Jennifer, Alisia, and others expressed the desire to be consistent over time in their spiritual and religious beliefs, actions, and commitments.

\section{As a Mother/Father of Faith, I Am Called to Provide}

A second primary theme in parents' perceptions of what they can do and be was associated with providing for their children in various ways. Seventy-five percent of parents offered responses that fell into this category. In this context, mothers and fathers described providing in three areas of life, namely, parents reporting that they felt called to provide (a) support, (b) love, and (c) help, as we discuss and illustrate next.

Provide support. This theme involved providing emotional and spiritual support for children, including providing resources, being available, solving problems, building self-esteem, and challenging them. Thirty-one percent of mothers' "providing" responses and $24 \%$ of fathers' responses were in this subcategory. Noor, a Muslim mother, said the most important thing for her was

[T]o nurture my children. To make sure that any problems that they have, I have to help resolve. . . . You have to work with your children, and keep the open communication all the time. And you have to always be there for them.

Tara, a Latter-day Saint mother, shared what she does to provide support for her children:
I think that my main role is to be an emotional and spiritual resource, because I'm with the kids most of the time when they're at home. . . . I see myself as being a resource that's there for them when they need me. I also see myself as being . . . their cheerleader and mentor in things that they would like to try and skills and talents they would like to develop—and in facilitating that.

Amy, a Baptist mother, described her desire to encourage and build up her children's self-esteem by

trying to encourage them and to just let them know how much I respect and admire them-I'm going to get choked [up] here-and appreciate them as people and who they are and how proud I am of them.

Several fathers similarly wanted to be a source of support for their children. A Muslim father, Yuusif, wanted to "be available to them, to help them through various situations they face." Jared, a Baptist father, highlighted that, for him, being supportive meant being a good listener. To his children, he said, "I also just want to make sure that I'm there for you. I'm a good communicator. I'm a good listener... [a] sounding board."

Jake, a United Church of Christ father, emphasized the importance of simply being present in children's lives, "I think a lot of it is just being there and spending time with my children, and listening to them and playing with them. Challenging them to do better. And having fun together." Kurt, a Catholic father, in discussing being supportive, added, "Certainly you've got to be the motivating force that takes them through a lot of those things they don't want to do."

Provide love. In addition to providing support, parents in the study expressed that they felt called to provide love to their children. Thirty-one percent of mothers' providing responses and $21 \%$ of fathers' providing responses fell into this subcategory. Responses coded within this theme indicated the importance of giving and expressing love, including specific forms of love such as showing affection.

Kari, a Christian mother, spoke of the importance of consistently providing love to her children by saying, "Love them. Love them unconditionally through hard times that do come, and good times as well." Martha, a Lutheran mother, answered, "To be a loving person, I think that's the thing that I want to give my kids." Abby, a United Church of Christ mother, described ways she provided love to her children:

Having a lot of laughter and fun is a part of loving. When I think of loving, that's a lot of it. But there's a lot of good times. And also the being there, 'cause that's been ... one of the big influences that has made me choose ... to be here.

Fathers recognized the importance of providing love to their children. Jason, a Latter-day Saint father, expressed a desire to always love his children, despite imperfections:

I want my kids to know that I love them, even though I may be human and have frailties of losing my temper, raising my voice inappropriately, that I love them; because . . . I show them I love them . . . and care about them.

Brent, a Jehovah's Witness father, said, "I think love is probably the most important thing. Love of God, love of your family." Todd, a Baptist father, also described the importance of love, 
"Love by example ... [by] loving God and loving people, both family and non-family. I think has a huge influence."

Provide help. Mothers and fathers also expressed a desire to provide for their children's financial and physical needs and wellbeing. Twenty-two percent of mothers' and $24 \%$ of fathers' providing responses were in the provide help subcategory. A salient component of this subcategory is the acknowledgment of protection as one of a child's needs. Heidi, a Latter-day Saint mother, tied in protection as part of the temporal aid she needs to provide. In her words, she feels the need to "help them feel security, but yet give them skills to be able to live on their own." Carmen, a Seventh-day Adventist mother, regarded keeping her children from harm's way as her most noteworthy responsibility: "As a mother, my most important job is to keep them alive through the day."

Several fathers also included providing help with temporal things as part of their parental duty. Gary, a Methodist father explained, "My job is to . . . make sure that Jasmine has the things that she needs." Yuusif, a Muslim father, stated that part of his role is "to always look for [my children's] welfare and be available to them, to help them through the various situations they face." Evan, a Latter-day Saint father, quipped, "Well, I have to fund all of these adventures," referencing financial provision. Uriel, a Conservative Jewish father, described protection as the most important physical aid to offer: "The most important thing is to make sure the kids are safe. That's the most important thing. It's a dangerous world and you want to protect your kids." Samuel, a Baptist father, explained, "[I want our kids to have a] sense that our family is . . . a safe haven."

\section{As a Mother/Father of Faith, I Am Called to Teach}

The final primary theme that emerged was parents felt called to teach their children. Sixty-six percent of mothers and $55 \%$ of fathers offered responses that were coded in the teach category. Three recurring patterns were identified: (a) teach religious values, (b) teach the faith tradition, and (c) teach religious identity.

Teach religious values. The most prominent pattern to emerge within this theme was teaching religious values. Thirtyfive percent of mothers' and fathers' teach-related responses were coded in this subcategory. Narratives included parents who mentioned their desire to teach important religious principles, beliefs, and values.

Julie, a Latter-day Saint mother, said of her daughter, "I think it is my responsibility to raise her with the gospel principles, and share with her the significance of Heavenly Father and the joy of an eternal marriage." Amy, a Baptist mother, said, "I've tried to be honest about teaching them right from wrong from a biblical perspective." Kathy, a Catholic mother, explained her desire as a mother: "Teach them values I'd want them to have forever and ever."

Fathers' responses were quite similar. Ed, a Seventh-day Adventist father, explained, "I guess I have to go back to what it says in Deuteronomy Chapter 6 where it talks about teaching your children at all times what God has, what God's will is for us."

Alex, a Pentecostal Father, said,

[I] keep instructing my children to always be confident in the Lord, even though they will not see it now. . . Always be confident in the Lord, regardless of what the situation is. . . . I try to instill good Christian values into my children.
Teach the faith tradition. In addition to addressing values, parents described various ways they try to transmit their faith and sacred traditions to their children. Ten percent of mothers' responses and $14 \%$ of fathers' "teach" responses fell into this subcategory. A Jewish mother named Arella explained the importance of teaching her children religious traditions:

[I] try to pass on the traditions that are special and that are important. You know, how to make meals for the holidays. [Also, to] go to shul. My focus, I guess, is what happens at home. I mean we go to shul as a family. I go to shul, sometimes alone and sometimes the kids come with me. But in the house what I teach them is: This is how you set a Shabbas table, and these are the foods that you prepare for a traditional Sabbath meal, these are the foods that you prepare for a traditional Rosh Hashanah, which is [the] New Year's [celebration]. . . . I think teaching them how to make a Jewish home [is important], so that when they have a Jewish home, [they will not have] to look in a book.

Kathy, a Catholic mother, reflected,

If I can give one thing to my kids, it would be this faith. Not a bunch of money, not a bunch of whatever else. . . Not things at all. If they can have that [faith] in life, I would be fulfilled.

Fathers said similar things. Ron, a Conservative Jewish father, expressed,

In terms of Judaism, [I want] to give them a sense that this is a tradition that is worth preserving. To show them by example, and by instruction, that this is a tradition that commands respect, that deserves to be perpetuated, and that they have a responsibility to perpetuate it. But not out of ... obligation, but that this is worth doing. That it'll be a positive influence in their lives. This is part of the self-definition that we embarked on [in our marriage] 22 years ago. We [want to] set something in front of them that they would want to take, to be a part of themselves. I think it is of paramount importance that this tradition continue, and it can only continue by positive example. So the children have to see something there that's worth doing.

Eli, a Modern Orthodox Jewish father, said that he likewise felt a duty "to transmit the tradition in as far as I understand it."

Teach religious identity. The final pattern in the teaching theme centers on parents teaching religious identity to children through various means. By identity we mean a strong sense of self, connected with religious identity. Three times as many mothers' $(21 \%)$ as fathers' (7\%) narratives were coded in the identity subcategory. Asalah, a Muslim mother, explained, "I try to develop good character in the children and confidence. By being there for them, so they are strong in who they are." Hannah wanted "to connect my children with Jewish history; [to] make them understand their part of it." She specifically mentioned her children's identity as pertaining to their religion. Erin, an Episcopalian mother, shared what she learned from her mother about teaching children about their identity, as well as the relative worth of others:

I think my mom may have said something to the effect that what I want to pass on to my children is that my children are just as special as everyone else in the world, and no more special [than others]. That they are unique, wonderful individuals; but that doesn't make them better than anybody else. . . A sense of pride of who they are without having to demean who and what someone else is. 
Fathers also discussed the importance of teaching children their personal identity. Saul, a Jewish father, discussed the importance of his children's Jewish identity:

The most important thing I would like to give my kids is the desire . . . to grow in their Jewish identity; the desire that they should grow in deeper interest in knowing who they are; the scripture of Torah and learning it; the desire to pursue it.

A Muslim father, discussed specifically how his children have developed and stand up for their religious identity:

If they have struggled, the biggest struggle . . . has been because they look different, they do different things, they dress differently. And they have considerable peer pressure. For example, they do not date, they do not drink, they do not dress in certain ways, so there are some restrictions that they feel. And we have tried to provide them some alternatives for entertainment and things, and also to explain to them that: "Yes, you are different than everybody else, and you should be proud of the difference, and you shouldn't hide it, but tell people. And don't just practice certain things secretly, but try and explain to people why you don't do certain things. You know? Tell them proudly about your faith." I think, because they pray in schools, that's another thing which makes them different. . . . Hopefully we give them enough support that they can be themselves.

Yuusif also felt a need to ensure his children are confident in who they are as Muslims.

\section{Discussion}

Using qualitative analyses of in-depth interviews, we explored what exemplary mothers and fathers of various faiths (identity) considered the most important things (calling) for them to be (being) and to do (action). Identity-centered religious being and identity-centered religious action were coded and classified. Figure 1 presents a conceptual model illustrating how these concepts and findings are linked.

In response to the question, parents said they felt called to be (A1) an example, (A2) authentic, and (A3) consistent; to provide (B1) support, (B2) love, and (B3) help; and to teach (C1) religious values, (C2) the faith tradition, and (C3) religious identity. In reporting what they themselves wanted to be, parents focused not only on their children's actions but also on who and what their children were ultimately becoming, seemingly underscoring the inherently relational nature of being.

\section{Conceptual Model}

The conceptual model (see Figure 1) places identity at the center indicating its central place in both the concepts and findings. The shaded lines emanating up from identity indicate that the three concepts of religious calling, religious being, and religious action are centered in identity and that they are linked to each other. Each of the top three boxes includes the portion of our interview question (in quotes) pertaining to each concept. The three shaded lines emanating down from identity to the three boxes with major findings (called to be, called to provide, and called to teach) indicate that participants' identity as a religious parent strongly influenced the findings.

The three findings under "called to be" connect with the religious being concept and the three findings under "called to pro- vide" clearly fit under the religious action concept. Based on how parents spoke about teaching, the three findings under "called to teach" serve to integrate being and action; thus, we placed it between them in the model. For example, parents' accounts included language such as "I've tried to be honest about teaching them" (being) and "instructing my children to be confident" (being) as well as "This is how you set a Shabbos table" (action) and "teaching them how to make a Jewish home" (action) and "to show them by example, and by instruction" (being and action).

\section{Mothers and Fathers of Faith Were Similar}

Repeated statements by parents acknowledged personality and gender differences, but the couples frequently referenced the central importance of a shared family vision about their calling as mothers and fathers of faith (Marks \& Dollahite, 2012). This shared family vision among the exemplar families we interviewed may be a reason for the overall degree of similarity between mothers and fathers.

These data indicated that both mothers and fathers had similar desires to be good examples. Mothers and fathers of faith both reportedly rely on their religion to show them what (and how) they should try to be. Parents reportedly strived to model their relationship with their children in a manner consistent with their belief in God. Many reportedly drew on a commitment to God and their religious faith as a guide for what they should be as parents. Parents expressed their desires to be consistent examples and to live so that what they taught their children was demonstrated in their own behavior. Parents not only wanted to teach their children about their religious beliefs, they also reportedly strived to become models of what they were teaching their children.

Many parents expressed a sense of responsibility to provide spiritual, physical, and/or emotional support for their children in and outside the home. They spoke of the importance of being available and ready to help their children through effective communication. Parents reported that they felt responsible to provide emotional and physical security. Parents also wanted their religious practices, beliefs, and sacred traditions to live on through their children. Along with religious values, parents wanted to teach their children to have a strong, healthy sense of religious identity.

\section{Connecting Our Findings to Previous Research: Overall Findings}

Our findings are consistent with Mahoney and colleagues' (2003) findings that many parents view their parenting as having sacred significance. Parents' responses clearly indicated that they placed great spiritual significance on their relationship with their children - a finding that is not surprising, given the sample and focus of the study. Further, however, our findings echo those of Kluckhohn and Strodtbeck (1961), Papajohn and Spiegel (1975), and Dollahite and Walls (1993), namely, that the parents of faith we interviewed reported that they highly valued both authentic being and action (teaching and providing) in relation to their children.

Our findings also align with Schachter and Ventura's (2008) components of identity agency in multiple ways. Parents exhibited identity concern and related goals in that they strongly desired for their children to become the kinds of people their faith traditions 
encouraged. Parents reported a number of practices intended to help their children develop their identities in ways consistent with parents' most deeply held values. Parents manifested assessment and reflexivity in that they evaluated their performance as a mother or father of faith in how well they thought they were doing. Many reported making changes to improve. Parents also discussed a variety of implicit theories regarding how to best influence the religious identities of their adolescent children, including the importance of being an example, being authentic, and being consistent.

For the parents of this study, the most prevalent teaching-related concern was teaching their children religious values. This idea is captured in the Eriksonian concept of generativity, a concept that embodies a moral commitment to nurture and guide the next generation and to transmit lasting values. Continuing with the theme of guiding the next generation, parents shared a desire to teach their children about their faith and how they can live it throughout their lives. Even though transmission of faith tradition is likely to occur in religious homes, it is far from inevitable. However, Regnerus, Smith, and Smith (2004) found that when it does successfully occur, parent-child transmission of religiosity is often meaningful and potent (see also Bengtson, Putney, \& Harris, 2013).

Many would describe effective parenting as preparing children to competently and independently take on adult challenges in the world, as well as instilling in children the needed skills to protect themselves. Likewise, parents in our study wanted to instill independence and competence - and perhaps, most of all, a deep sense of personal and religious identity (i.e., "I want them to be an honorable and faithful Catholic.").

\section{Specific Finding: What to Be and to Do}

The concepts of responsible and relational religious being and religious action are inherent within the Abrahamic religions-and it seemed that for many of our participants, their faith community served to encourage parental responsibility (Agius \& Chircop, 1998). The values and beliefs within these faiths are often focused on ways of being and processes of becoming, rather than merely a spiritual "to-do list." Indeed, most religions ask individuals to continually strive to become their best selves-or to change to become something better or more than they now are. This journey toward being something more is a life-long process that permeates each stage of life, including childhood and parenthood. The religious parents we interviewed were concerned in deeply relational ways about who they and their children are as well as who they are trying to become.

\section{Specific Finding: Importance of Authenticity}

Pargament and Mahoney (2005) found that parents who aspired to live in a manner congruent with their religious beliefs tended to invest more effort in being committed to their role as parents. Perhaps these types of parents are also likely to model effective actions as they teach and instill moral behavior in their children. An oft-heard charge against religious persons is hypocrisy-a charge referenced and occasionally justified in our data. Indeed, some use piety as a cloak to mask a personal life grossly inconsistent with their stated beliefs. Nearly all of the highly religious people in our sample acknowledged that they were unable to fully live up to the ideals of their faith. Participant parents wanted to be authentic and real with their children-and avoid the inconsistency inherent in hypocrisy. For many, it was not enough to tell their children about their beliefs; they aspired to personally be better and live by what their religion teaches. Being authentic was more important to them than appearing perfect.

Of particular interest was the congruency between the responses of mothers and fathers. Consistent with evolving and more egalitarian gender norms, we found that mothers talked about keeping their children safe just as often as fathers did and that many fathers (like mothers) desired to be fully present and loving in their children's lives.

\section{Limitations}

Our sample is relatively small and geographically limited (to two states in New England). The small number of families of diverse faiths (e.g., Muslims) means the findings certainly are not generalizable. Indeed, the methodology does not allow for causal determination or generalization to broader samples. The fact that families were interviewed together means that they were somewhat dependent on each other, and thus findings could have overstated similarity between husbands and wives because one spouse could have heard the other state something and concur without fully believing it. Conversely, our findings could have understated similarity if one spouse heard the other say something and not repeated it because the point had already been made.

Close inspection of the numbers of cases reported in Table 1 indicates some data limitations on subthemes in two of the three major themes. The frequency of accounts across the three major themes are fairly evenly distributed with 45,43 , and 35 total accounts. However, although the number of cases in the three subthemes in the "called to provide" theme was fairly balanced $(16,15$, and 12 cases), the second and third subthemes for the other two major themes ("called to be" and "called to teach") occurred substantially less frequently $(32,7,6$; and $20,7,8)$. Therefore, the number of cases in the second and third subthemes combined were less than half of the first subtheme.

Additionally, having only six of the 58 parents tell stories about being consistent and the similarly small numbers for being authentic, teaching the faith tradition, and teaching religious identity means that these subthemes reflect between $10 \%$ and $15 \%$ of the sample, and are thus relatively minor elements of the being and teaching constructs (compared with the common feature of being an example that was mentioned by more than half of the parents). These small numbers raise the possibility that these components are more idiosyncratic to our sample rather than suggestive of broad patterns among all parents. This small number of cases in this exploratory study highlights the tentative nature of these data.

\section{Implications for Education, Counseling, and Research}

Great diversity exists within and among the Abrahamic faiths and also among educators, clinicians, and scholars. Those of various perspectives will interpret and draw different implications from our findings. Thus, we offer these implications tentatively. 


\section{Implications for Religious and Secular Education and Counseling}

Findings of this study emphasize the importance of identitycentered religious calling, being, and action and how they influence spiritual formation. Secular clinicians, counselors, and family life educators (unless they have been trained in "person-centered" approaches) are not likely to focus on being or calling. Most tend to address processes (e.g., communication, problem-solving, relational patterns), cognitions (e.g., beliefs, thought patterns, assumptions), behaviors (e.g., rewards, punishments, parenting actions), and affect (e.g., feelings). These vital domains take on added depth, however, when coupled with a sense of ultimate purpose and meaning (Dollahite, Marks, \& Olson, 2002; Marks \& Dollahite, 2011).

Many religious leaders likely focus their sermons and pastoral counseling on the "deep things of the soul" because they are trained, called, and expected to do so. Our findings suggest that many religious parents likely would welcome additional attention to how they can become more authentic role models of faith for their children. Palkovitz (2002) found that some parents take an "outsourcing" approach to religion (e.g., delegate it to youth ministers) because the parents are not confident in their own abilities. Such parents might welcome focused, encouraging exploration regarding how to better teach, support, protect, and mentor their own children in matters of faith. Many parents want to have authentic, faith-building dialogue with their children but are unsure how to do so. Clergy and religious educators who find creative ways to promote meaningful conversations between parents and children can help with this (Dollahite \& Thatcher, 2008). Parents-particularly fathers-value effective online parenting education (Morris, Dollahite, \& Hawkins, 1999).

Religious and secular educators might also consider how to teach religious and nonreligious parents to be authentic role models of what they deeply believe. Those who work with religious parents might focus attention on how to balance being an authentic spiritual role model while also avoiding religious and spiritual perfectionism.

Pastoral and secular counselors working with religious parents and youth might focus attention on those struggling with perceived inauthenticity or hypocrisy. Counseling might also be needed for religious parents and youth struggling under the pressure of trying to live high, religiously based ideals in opposition to cultural pressures that often counter religious standards. Counselors can help parents and youth with tendencies toward obsessivecompulsive religious adherence (religious or spiritual perfectionism) to find a balance between upholding high, religiously based ideals and being a flawed but an improving and developing human being.

\section{Future Research}

We conclude with some thoughts on future research on identitycentered being. What does it mean "to be"? Should social science research and behavioral practice even address this question? Our religious exemplar respondents focused on being authentic (honest, real) and being a role model (living the faith) as the most important things for them to be as parents of faith. However, when it comes to things "close to home," Annette Mahoney has found that many nonreligious people also tend to "sanctify" marriage, family, and parenting (Mahoney et al., 2003). It may be that nonreligious parents would provide similar answers to questions about what they should be as a parent. Trying to honestly live what one deeply believes likely is what any good parent, religious or not, strives to do for their children. Research should test this.

In the bottom-line culture and economy that we inhabit, with its increasing emphasis on rigorous quantitative assessment of outcomes, it may seem quaint to suggest that scholars, educators, and clinicians focus more attention on being and becoming. Despite the bureaucratic imperative for measurable outcomes in politics, education, and the workplace, human beings are no less in need of sustained and meaningful attention to the deepest aspects of being a person than people were during previous slower-paced and perhaps more person-centered eras. Human beings have not ceased to contend with what Viktor Frankl (1984) identified as "the existential vacuum" (p. 128).

In our view, social and behavioral scholars and practitionersespecially those who study religion, psychology, and family lifeshould not meekly submit to the ever-increasing focus on behavioral outcomes and what people in various contexts produce and/or consume. Rather, we believe that scholars and practitioners who care about religion, marriage, family life, parenting, and youth development should attend to matters of personhood, becoming, and humanity among the persons they study and serve. As society becomes more demanding of its people to produce and consume, perhaps one of the greatest contributions social scientists and practitioners can offer is attention to the deepest, most relational, and most meaningful aspects of being human.

\section{Conclusions}

Shakespeare's Hamlet asked, "To be, or not to be?" Any of us can ask ourselves, "Will I choose to be, or not to be, my better self?" In other words, will I hold to my deepest beliefs and commitments or will I give in to various forces that invite and entice me to be less than I want to be-and less than what those whom I love need me to be? We hope that scholars and practitioners will find creative ways to ask others to explore these and other identity-centered questions about calling, being, and action. Our study is only one preliminary, exploratory step along this path. We hope to see many studies that attend to the deeper, existential questions that concern human beings as they consider what is most important for them to be, to do, and to become. We believe that this can make for better scholarship, better practice, and better lives. We may even be able to help more people avoid coming to the end of their lives and experiencing the existential crisis of what Ware (2011) reported as "the regret of not having lived a life true to themselves" (p. 39). Perhaps the item "be true to myself and those I love" should be at the top of the bucket list of every human being striving to become fully human.

\section{References}

Agius, E., \& Chircop, L. (1998). Caring for future generations: Jewish, Christian, and Islamic perspectives. Westport, CT: Praeger.

Babbie, E. (2004). The practice of social research (10th ed.). Belmont, CA: Wadsworth. 
Bellah, R. N., Madsen, R., Sullivan, W. M., Swidler, A., \& Tipton, S. M. (1985). Habits of the heart: Individualism and commitment in American life. Berkeley, CA: University of California Press.

Bengtson, V. L., Putney, N., \& Harris, J. (2013). Families of faith. New York, NY: Oxford University Press. http://dx.doi.org/10.1093/acprof: oso/9780199948659.001.0001

Coulson, J., Oades, L. G., \& Stoyles, G. (2012a). Parent's conception and experiences of calling in child rearing: A qualitative analysis. Journal of Humanistic Psychology, 52, 222-247. http://dx.doi.org/10.1177/ 0022167810382454

Coulson, J., Oades, L. G., \& Stoyles, G. (2012b). Parents' subjective sense of calling in childrearing: Measurement, development, and initial findings. The Journal of Positive Psychology, 7, 83-94. http://dx.doi.org/10 $.1080 / 17439760.2011 .633547$

Daly, K. J. (2007). Qualitative methods for family studies \& human development. Thousand Oaks, CA: Sage.

Damon, W., \& Colby, A. (2013). Why a true account of human development requires exemplar research. In M. K. Matsuba, P. E. King, \& K. C. Bronk (Eds.), Exemplar methods and research: Strategies for investigation. New directions for child and adolescent development (Vol. 142, pp. 13-25). New York, NY: John Wiley \& Sons. http://dx.doi.org/10.1002/ cad.20046

Dollahite, D. C., Marks, L. D., \& Olson, M. M. (2002). Fathering, faith, and family therapy: Generative narrative therapy with religious fathers. Journal of Family Psychotherapy, 13, 259-294. http://dx.doi.org/10 .1300/J085v13n03_03

Dollahite, D. C., \& Thatcher, J. Y. (2008). Talking about religion: How religious youth and parents discuss their faith. Journal of Adolescent Research, 23, 611-641. http://dx.doi.org/10.1177/0743558408322141

Dollahite, D. C., \& Walls, S. H. (1993). A cross-cultural study of parental value orientations and parental involvement in adolescent children's education. Family Perspective, 27, 393-414.

Erikson, E. (1968). Identity, youth and crisis. Oxford, UK: W. W. Norton.

Erikson, E., \& Erikson, J. M. (1997). The life cycle completed: Extended version. New York, NY: Norton.

Frankl, V. (1984). Man's search for meaning: An introduction to logotherapy. New York, NY: Simon \& Schuster.

Gilgun, J. F. (2005). Deductive qualitative analysis and family theory building. In V. L. Bengtson, D. Klein, A. Acock, K. Allen, \& P. Dilworth-Anderson (Eds.), Sourcebook of family theory and research (pp. 83-84). Thousand Oaks, CA: Sage.

King, P. E. (2003). Religion and identity: The role of ideological, social, and spiritual contexts. Applied Developmental Science, 7, 197-204. http://dx.doi.org/10.1207/S1532480XADS0703_11

Kluckhohn, F. R., \& Strodtbeck, F. L. (1961). Variations in value orientations. Evanston, IL: Row, Peterson.

Lofland, J., Snow, D. A., Anderson, L., \& Lofland, L. H. (2005). Analyzing Social Settings: A Guide to Qualitative Observation and Analysis (4th ed.). Belmont, CA: Wadsworth Publishing.

Mahoney, A., Pargament, K. I., Murray-Swank, A., \& Murray-Swank, N. (2003). Religion and the sanctification of family relationships. Review of Religious Research, 44, 220-236. http://dx.doi.org/10.2307/3512384
Marks, L. (2015). A pragmatic, step-by-step guide for qualitative methods: Capturing the disaster and long-term recovery stories of Katrina and Rita. Current Psychology: A Journal for Diverse Perspectives on Diverse Psychological Issues, 34, 494-505. http://dx.doi.org/10.1007/ s12144-015-9342-x

Marks, L. D., \& Dollahite, D. C. (2011). Mining the meanings from psychology of religion's correlation mountain. Psychology of Religion and Spirituality, 3, 181-193. http://dx.doi.org/10.1037/a0022206

Marks, L. D., \& Dollahite, D. C. (2012). "Don't forget home": The importance of sacred ritual in families. In J. Hoffman (Ed.), Understanding religious rituals (pp. 186-203). New York, NY: Routledge.

Maslow, A. H. (1998). Toward a psychology of being (3rd ed.). New York, NY: Wiley.

Mead, R. (2014). Kicking the bucket list. The New Yorker. Retrieved from http://www.newyorker.com/culture/cultural-comment/kicking-thebucket-list

Morris, S. N., Dollahite, D. C., \& Hawkins, A. J. (1999). Virtual family life education: A qualitative study of father education on the World Wide Web. Family Relations, 48, 23-30. http://dx.doi.org/10.2307/585678

Palkovitz, R. (2002). Involved fathering and men's adult development. Mahwah, NJ: Erlbaum.

Papajohn, J., \& Spiegel, J. P. (1975). Transactions in families. New York, NY: Jossey-Bass.

Pargament, K. I., \& Mahoney, A. (2005). Sacred matters. International Journal for the Psychology of Religion, 15, 179-198. http://dx.doi.org/ 10.1207/s15327582ijpr1503_1

Regnerus, M. D., Smith, C., \& Smith, B. (2004). Social context in the development of adolescent religiosity. Applied Developmental Science, 8, 27-38. http://dx.doi.org/10.1207/S1532480XADS0801_4

Reiss, S. (2015). The 16 strivings for God: The new psychology of religious experiences. Macon, GA: Mercer University Press.

Rogers, C. R. (1975). Empathic. The Counseling Psychologist, 5, 2-10. http://dx.doi.org/10.1177/001100007500500202

Schachter, E. P., \& Ventura, J. J. (2008). Identity agents: Parents as active and reflective participants in their children's identity formation. Journal of Research on Adolescence, 18, 449-476. http://dx.doi.org/10.1111/j .1532-7795.2008.00567.x

Seligman, M. E. P. (2002). Authentic happiness: Using the new positive psychology to realize your potential for lasting fulfillment. New York, NY: Free Press.

Seymour, J., Dix, G., \& Eardley, T. (1995). Joint accounts: Methodology and practice in research interviews with couples. York, UK: University of York.

Strauss, A., \& Corbin, J. (1998). Basics of qualitative research. Thousand Oaks, CA: Sage.

Tillich, P. (2014). The courage to be (3rd ed.). New Haven, CT: Yale University Press.

Ware, B. (2011). The top five regrets of the dying. New York, NY: Hay House.

Received September 25, 2015

Revision received December 15, 2016 Accepted February 14, 2017 